\title{
IMPLEMENTING EMPOWERING SOCIETY THROUGH SOUVENIR WORKSHOP WITH PEKALONGAN'S BATIK AS LOCAL INSPIRATION (STUDY CASE : KRAPYAK DISTRICT PEKALONGAN - CENTRAL JAVA)
}

\author{
Amarena Nediari, Titi Indahyani, Maryani \\ Bina Nusantara University, Indonesia. \\ anediari@binus.edu
}

\begin{abstract}
Empowering society is the main spirit of community service programs carried out by Bina Nusantara University. This provides benefits and enrichment for both parties, lecturers as educators as well as the fostered community. Pekalongan as a creative city needs to always develop its potential. Therefore the aim of the workshop is to enhance the insight in applying the local inspiration of Pekalongan's batik in various way such as souvenirs. The main idea of this workshop is to utilize batik waste into unique souvenirs design. As zero waste has become a worldwide culture, it is good for Indonesian people to participate in this environmentally friendly program. The workshop given from the lecturers PKK member in Krapyak district, Pekalongan. It is not only in terms of technical production but also an understanding of design principles. This research applied practice based research through workshop project for PKK member in Krapyak District, Pekalongan. This workshop is an experimental project for the participants that can encourage them to explore more about batik waste and its application and implement their knowledge in design element through their idea of souvenir's design. Hopefully the outcomes of this research can improve the applicaton of local inspiration in souvenir so as to actively contribute in preserving batik and introducing it to the younger generation of Indonesia.
\end{abstract}

\section{Keywords : Empowering Society, Workshop, Local Inspiration, Souvenirs, Design Principles}

\section{INTRODUCTION}

Empowering society is an effort to provide strength or reinforcement to the community. In this case community empowerment also means the ability of individuals to be united with the community in building the empowerment of the community so that it aims to find new alternatives in community development. (Prof. Dr. Ir. Totok Mardikanto, 2010). This activity requires a stronger party to support those who are not too strong. Starting with CSR (Corporate Social Responsibility) a form of corporate concern for the community is translated into a variety of social activities that show an intention to help the community without strings attached. This makes conditions felt biased and unbalanced, where the people being helped cannot do something in return. The development of CSR activities has grown into an activity that is mutually supportive and beneficial to both parties. Although it begins with supporting the weak, this relationship develops into reciprocity where the party assisted can eventually develop themselves to build their community. This community empowerment is an effort to motivate and encourage the community to explore their potention in order to improve their quality of life through education (Karsidi, 2001).

On December $1^{\text {st }}, 2014$, the city of Pekalongan officially received "A world creative city from UNESCO in the category of crafts and folk art". In fact it is the only creative city in Southeast Asia (Pujangga, 2014). Kota Pekalongan is a member of the UNESCO Creative Cities Network along with 68 other cities in the world. Known as the city of batik, the city's economy is also based on the batik business. In 2015, Pekalongan owned 830 Small and Medium Enterprises (SMEs) of batik that produced various motifs, materials and colors of Pekalongan (Admin, 2015). Batik for Pekalongan people is not only seen in terms of the economy, but also culture. Each SMEs has a minimum 15 workers, so this is one of the fields to accomodate labor. Pekalongan local government organizes batik activities and has Batik Technology majors in Pekalongan University, it was made to introduce batik to the younger generation and the world so that batik can continue to be preserved. Pekalongan also has developed a strategic plan in creativity based tourism. It is an innovative business which has changed the tourism paradigm in Indonesia. This change is caused by tourists need to be more engaged with the place they visited. The experience gained by tourists is an original experience, which provides knowledge and insight. (Damayanti, 2015). Consider to several aspects above Pekalongan is the destination for empowering society that organized by Community Development Academic with Interior Design Department, Bina Nusantara University.

The condition of the Pekalongan people who are already creative, needs a fresh idea that can spark other ideas that ultimately can provide a novelty in their creation. The team from CDA and Interior Design Department provide workshops to PKK (Family Welfare Development) member who is actively carry out various activities. They are trained to be creative in making household handicrafts that are of value for sale. The basic idea is that PKK member have a skill that can be continued to produce original products, has economic value and 
reproduced sustainably. This condition will indirectly have a positive impact on PKK member by providing additional income, activities to fill leisure time and skills in making crafts.

Batik as the local inspiration is no longer an old-fashioned product and it is not limited to fashion, but also can be applied into a variety of interesting products. Batik can also be used as a decoration element in an interior that can be used as souvenirs for both domestic and international tourist. This has also been done by team from Interior Design Department in collaboration with HDII / Indonesian Interior Designers Association in exhibition 'Finding Space in Batik' for commemoration of Batik Day in 2016 at National Museum, Central Jakarta (Prodjo, 2016). As a lecturer and interior designer, it is very important to provide education to public about application batik in a space using design principles. Thus, people can explore batik as an inspiration for interior decor. Nowadays, batik is not only used in traditional way, but has also been produced into a variety of fashion design from formal to casual, for men and women with various size from children to adults. This process produces a lot of waste so that it needs to reused into other objects that are useful and have economic value. Necklaces, brooches and bags are some of women accessories that used batik waste.

This study implementing the empowering society through souvenirs workshop with Pekalongan's batik as local inspiration. Hopefully the outcomes of this research can improve the application of local inspiration into souvenir design applying the design principles by utilizing batik waste. This is an effort to actively contribute to preserve batik and introduce Pekalongan's batik to the younger generation of Indonesia.

\section{METHODS}

This research applied practice based research through souvenirs workshop project for PKK member in Krapyak District, Pekalongan - Central Java. The material presented to participants is not only consisted of production techniques but also provided insights for design element. The workshop is also an experimental project for the participants that can encourage them to explore more about batik waste and its application and implement their knowledge in design element through creating souvenirs design. This research involves lecturers as instructors at workshops held on site. The instructor has prepared material for presentations and items needed in the workshop activities. Samples are made to provide references to the participant so that they understand the goals of the workshop.

\section{RESULT AND DISCUSSION}

Community empowerment has three main strategies, they are traditional, direct action and transformation. (Hikmat, 2006). Direct action is the strategy that carried out in the implementation of empowering society in Desa Krapyak. Due to limited time and located outside Jakarta this strategy is appropriate in terms of participants and type of workshop held in Pekalongan by CDA and team from BINUS University. Direct action strategy requiring the dominance of interest that are respected by all parties involved, in terms of changes that might occur. Within this strategy there are parties who are very dominant in making decisions. A workshop is a period of discussion or practical work on particular subject in which a group of people share their knowledge or experience (W Hanny, 2018). Hosted by lecturer from Interior Design Department Bina Nusantara University this workshop was participated by 6 member of PKK Krapyak in Desa Krapyak, Pekalongan - Central Java.

Krapyak is in the northern region in Pekalongan. It has a complete community structure from fisherman, farmers, entrepreneur, employee and clerics as well. This district is known for their beliefs in Islam is closely related to daily life of its people. The word 'Krapyak' comes form the sound of the waves on the north coast. Desa Krapyak divide into two area, there are Krapyak Lor (north) and Kraplay Kidul (south). Other than that Krapyak is also known as Batik center. One of the most well-known motifs is 'Jlampriang batik' which believed to be the original Pekalongan batik motif that found by Muslim craftsmen from Arabia. Based on the pattern Jlamprang batik is a geometric decoration (Amiroh, 2015).

Design principles are the rules for designer to follow in order to create an effective composition that cleanly delivers a message to its audience. The most fundamental principles of design include form, repetition, structure, repetition, similarity, gradation, anomaly and contrast (Wong, 1972). The importance of applying design principles is to provide a strong concept, give the meaning to design itself, and make it easy to mass-produce. The design principles delivered as part of the brief. It was given in advance so that the participants will be able to explore the idea of utilizing batik waste into souvenirs. 


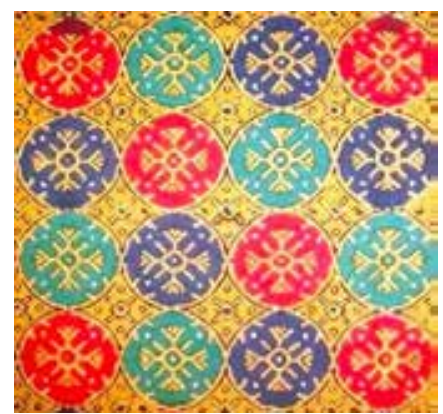

Figure 1. Jlamprang batik, the original Pekalongan batik motif (source : Priangga, 2018)

On figure 1 the Jlamprang motif as one of the inspiration for souvenir design, the design principles that applied in this motif are the repetition of circular form and structured with 3 different colors that diagonally arranged. Bright colors is one of the characteristic of coastal batik.
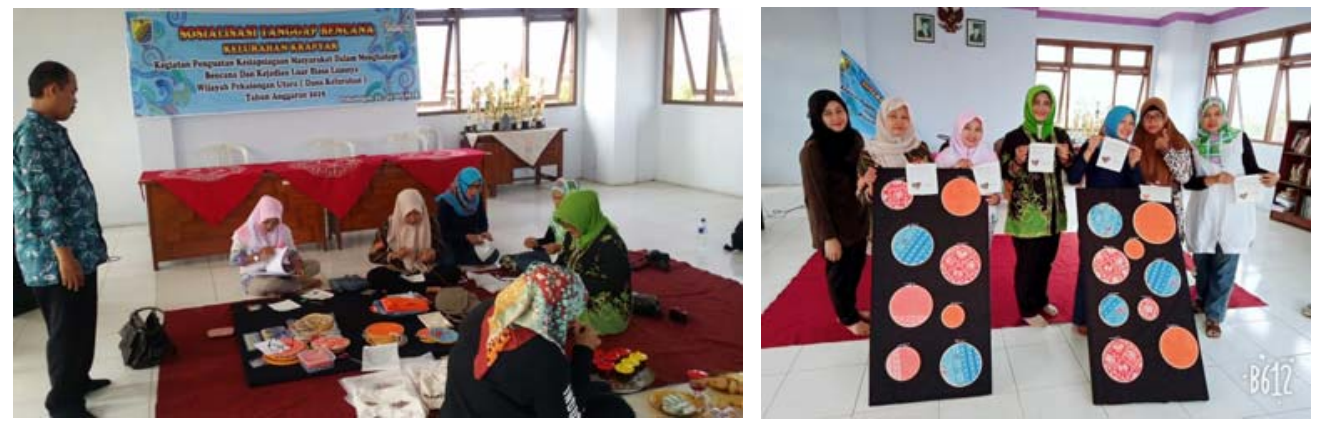

Figure 2. Making souvenirs utilizing batik waste (source : Titi, 2019)

On figure 2 the workshop was held in local government office at Krapyak District for 4 hours. There are 6 participants from PKK Krapyak joined this workshop. This workshop provides an opportunity to be able to make direct observation in terms of difficulty in understanding the delivered material, production technique and applying the design principles when producing the souvenirs. There are 2 types of souvenirs with batik waste used as the basic material. This was done to give references to participants to not only focused on one design. The 2 types of souvenir produced at this workshop are: 1). Drawstring bag in appliqué technique and embroidery, 2). Embroidery hoop art. Other supporting equipment are scissors, needles, thread, glue gun, white rope and wooden embroidery hoops in S, M and L size. All the equipment needed is easily found in traditional markets at affordable prices.
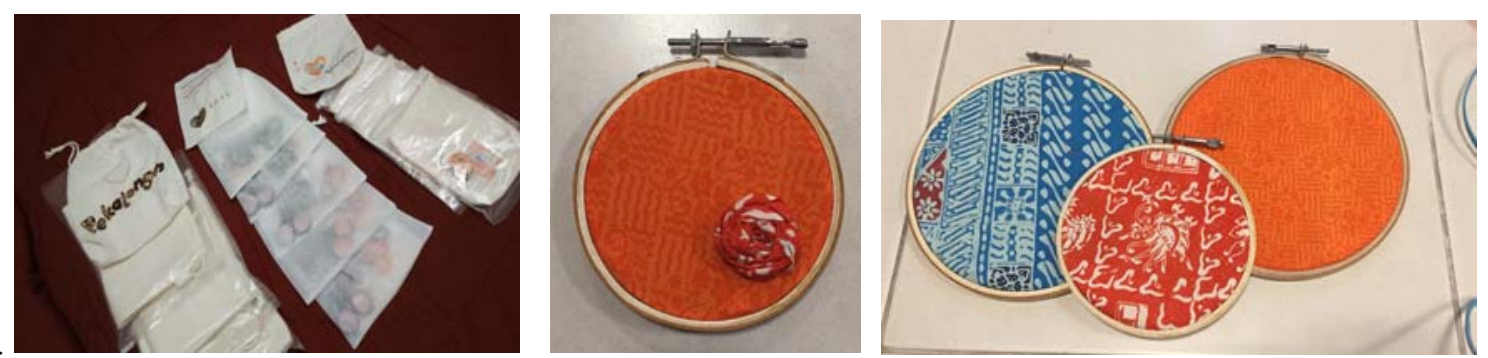

Figure 3. The results of the souvenir workshop in Krapyak District, Pekalongan (source : Titi, 2019)

On Figure 3 as shown above there are 2 types of souvenirs produced in the workshop. The $1^{\text {st }}$ souvenir is drawstring bags used appliqué technique and embroidery with batik waste composed as the alphabets for the the words 'Pekalongan'. This bag has 3 different size that can be useful for various purposes. It is also able to use as the packaging of other products, which this might give another opportunity to produce the bag to supply other parties who need packaging to wrap their goods. The $2^{\text {nd }}$ souvenir is embroidery hoop art. It is a new inspiration in using embroidery hoops as decor elements. It applied the design principles for contrast in color and structured 
in different size. Participants were also given additional insights to calculate production and sales price as a result from this workshop participant could develop their ideas and sustainably produce them.
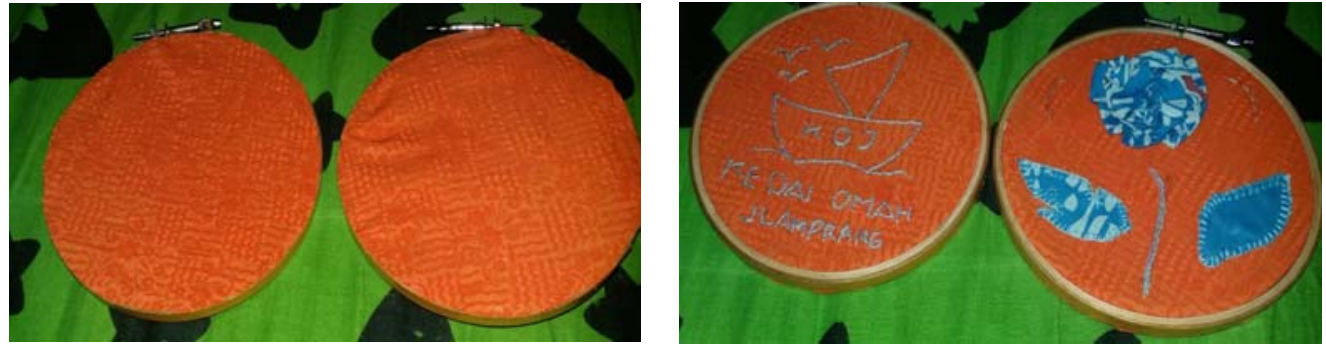

Figure 4. The result of embroidery hoops art with appliqué technique and embroidery

(source : Titi, 2019)

On figure 4 these are before and after of making embroidery hoops art. The stages carried out in the production of embroidery hoops art were color selection, pattern settings and the neatness in worksmanship. They are using appliqué and embroidery technique, using contrast color to make the pattern looks stand out.
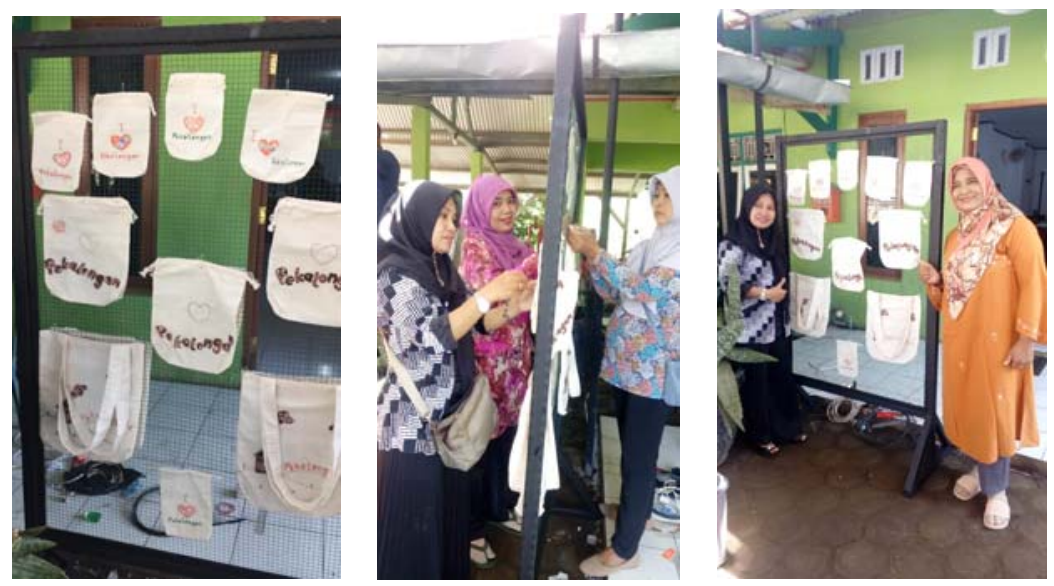

On figure 5 the souvenirs arranged on a stand to display. After completing the workshop empowering society for PKK member is continued with displaying the souvenirs on display stand. They are now ready for sale. It is necessary to maintain the good relation with the participants. It is not only to keep track on their activities post the workshop, but also can be continued as opportunities for the next activities.

\section{CONCLUSION}

The activities that researchers has delivered to the member of PKK Krapyak through practise based method had shown satisfactory outcomes in general. The participants' response of this project was good which the results of the workshop had shown understanding of design principles. Participants have good basic skills in embroidery. This greatly facilitates the implementation of workshops so that the material can be delivered properly.

They also managed to continue the activities on their own and finish them so they are able to display the souvenir on a stand. They also put the stand in Balai Keswadayaan Masyarakat (BKM) for temporary exhibition. The empowering society that held in Krapyak district has given an opportunity to improve skill and add insight to member of PKK Kryapyak. It is expected that these skills can be used and developed so they are useful and beneficial for the community in Krapyak district.

\section{REFERENCES}

Admin. (2015, September 16). Kota Pekalongan, Kota Kreatif Pertama di Indonesia. Retrieved August 6, 2019, from Kota Kreatif Indonesia: http://kotakreatif-id.blogspot.com/2015/09/pekalongan-kota-kreatifpertama-di.html

Amiroh, B. R. (2015). Mengungkap Asal Usul Nama Keluruahan di Kota Pekalongan . (C. Pekalongan.com, Producer, \& JP Media Network) Retrieved August 7, 2019, from Cinta Pekalongan : https://www.cintapekalongan.com/sejarah-asal-usul-kelurahan-krapyak-kota-pekalongan/ 
Damayanti, M. L. (2015). Strategi Kota Pekalongan dalam Pengembangan Wisata Kreatif Berbasis Industri Batik. Jurnal Pengembangan Kota , 3 (2).

Hikmat, H. (2006). Strategi Pemberdayaan Masyarakat (Vol. 1). Bandung, Jawa Barat, Indonesia: Humaniora Utama Press (HUP).

Karsidi, R. (2001). Paradigma Baru Penyuluhan Pembangunan dalam Pemberdayaan Masyarakat . Mediator Jurnal Komunikasi , 2 (1), 115-125.

Pujangga, R. F. (2014, December 10). UNESCO Akui Kota Pekalongan sebagai Kota Kreatif Dunia . (T. Jateng, Producer) Retrieved August 5, 2019, from Tribun Jateng.com: https://jateng.tribunnews.com/2014/12/10/unesco-akui-kota-pekalongan-sebagai-kota-kreatif-dunia

Priangga, G. P. (2018). Sejarah Batik Jlamprang Motif Khas Pekalongan . (C. Pekalongan, Producer, \& JP Media Network) Retrieved August 8, 2019, from Media Informasi dan Referensi : https://www.cintapekalongan.com/sejarah-batik-jlamprang-motif-khas-kota-pekalongan/

Prodjo, W. A. (2016, 09 2009). Akhir Pekan Rayakan Hari Batik Nasional di Museum Nasional . (K. Palmerah, Producer) Retrieved August 7, 20i9, from Kompas.com https://ravel.kompas.com/read/2016/09/29/160800327/akhir.pekan.rayakan.hari.batik.nasional.di.muse um.nasional

Prof. Dr. Ir. Totok Mardikanto, M. (2010). CSR - Corporate Social Responsibility (Tanggun Jawab Sosial Korporasi) (Vol. 1). Bandung, Jawa Barat, Indonesia : Alfabeta.

W Hanny, N. A. (2018). Implementing Cultural Identity in Global Perspective Through Contemporary Art (Study Case of " Through" Workshop in Beijing, China). International Conference on Language, Literature, Culture and Citizenship. Tangerang : BINUS University

Wong, W. (1972). Principle of Two Dimentional Design (Vol. 10). New York, New York, USA: John Wiley \& Sons. 